\title{
Development of Stop Motion Mathematics Animation
}

\author{
Anggita Putri Lestari ${ }^{1}$, Leonard ( $\left.{ }^{2, *}\right)$, Zulfiati Syahrial ${ }^{3}$, Syafa'atun ${ }^{4}$ \\ 1,2,4Program Studi Pendidikan Matematika, Universitas Indraprasta PGRI, Jl. Nangka No. \\ 58c Tanjung Barat, Jakarta Selatan, DKI Jakarta, Indonesia. \\ ${ }^{3}$ Program Pascasarjana Universitas Negeri Jakarta, Jl. Rawamangun Muka, Jakarta Timur, \\ DKI Jakarta, Indonesia.
}

Received: July 03, 2020

Revised: August 22, 2020

Accepted: August 23, 2020

\begin{abstract}
This development research aims to find out the product of the development of mathematics learning media that can provide solutions to the problems of mathematics learning class III of elementary school. The research method used is the Research and Development method with the ADDIE development model (Analysis, Design, Development, Implementation, and Evaluation). In this study to determine the feasibility of stop motion mathematical product learning media, the product was tested to two media experts and three material experts. Based on the results of the evaluation at the stage of evaluation of stop motion mathematics animation learning media, it can be concluded that learning media are in good categories and suitable for use in the learning process.
\end{abstract}

Keywords: Instructional media, animation, stop motion video, mathematics.

(*) Corresponding Author:

leo.eduresearch@gmail.com / 081382939050

How to Cite: Lestari, A.P., et al. (2020). Development of stop motion mathematics animation. Formatif: Jurnal Ilmiah Pendidikan MIPA, 10 (2), 77-90. http://dx.doi.org/10.30998/formatif.v10i2.6563

\section{INTRODUCTION}

Mathematics is one of the lessons that have an important role in life (Siregar, 2017; Asma, 2017), so it needs to be given to all students starting from elementary school (Muchlis, 2012; Hernaeny, 2015). Mathematics is important because it is a lesson that underlies all branches of science (Oktavia, 2017) and underlies the development of modern technology that plays a role in various disciplines and advances human thinking (Meidawati, 2014). For this reason, mathematics is often said to be the queen of science, because many other sciences whose findings depend on mathematics (Wahyudi, 2018) in learning mathematics are very much needed deep thinking skills (Leonard, 2016). That is why there are problems faced in mathematics in the field of education today namely, the assumption of some students in school about mathematics which is one of the lessons that are considered problematic and frightening (Peranginangin, 2019; Setyaningrum, 2017; Siregar, 2017; Putra, 2016).

One of the factors that make students difficult to learn mathematics is skills in solving mathematical problems (Tambychik, 2010). Besides that, it is also hampered by the limitations of the learning media used by the teacher and the school in facilitating student teaching and learning activities (Prastya, 2016) and the delivery methods used by the teacher in learning activities are inaccurate and less varied (Arnis, 2017; Khotimah, 2017). In teaching and learning activities, teachers are not always able to make students understand the actual objects. Therefore, learning media are needed (Primasari, 2014) because it can help students describe various kinds of abstract mathematical objects (Berney, 2016), increase student learning interest (Ogochukwu, 2010), and make the learning process fun (Cope, 2015). For these reasons, in the learning process of 
mathematics, the role of learning media is needed to improve students 'skills (Setyaningrum, 2017). Furthermore, the use of learning media in the teaching and learning process can also increase students' interest and motivation (Wiratmojo, 2002).

So far, schools only use learning media such as: textbook or modules, whiteboards, and teaching aids that never change with the times, resulting in students in this globalization era lacking interest and motivation in the process of learning mathematics. For this reason, it is the obligation of the teacher to determine learning media that are in line with technological developments (Prastya, 2016) because innovation is the goal of solving a problem (Gibbons in Hokanson, 2014). In this case there must be a system renewal in mathematics teaching including learning media. The interactive one reduces the majority of lazy, less motivated students (Azizah, 2016). This should not be ignored (Mahnun, 2012) because the media in learning has a function as a tool to clarify the message conveyed by the teacher (Kurniawan, 2017).

Learning media that fit the needs of students at this time are technology-based learning media (Kurniawan, 2017). The development of learning using technology is an effort to improve the quality of the learning process (Suparman, 2014) in accordance with current developments. Technologies used in learning mathematics is computer-based because it is expected to help students learn mathematics at different levels of abstraction (Liana, 2016). The developed computer-based learning media provided a lot of animated films (Astriani, 2018). Multimedia acts as a mediator between problems in the real world and the world abstract of mathematical knowledge because multimedia media consists of audio and visual elements or text and illustrations (Listudentnti, 2015). One of the popular multimedia learning media today is media stop motion.

Stop motion is an animation technique that manipulates images so that a stationary object can appear to move and depend on the calculation of the frame. So, stop motion animation is a process of stopping movement. In animated films, there is a union of graphics and sound, which can concretize learning material. Animated film media is very suitable for using by elementary school teachers, given the characteristics of elementary school students who like colorful images, and interesting stories. If students can understand the concept of learning material and its application in a concrete manner, students will be able to find and use the learning outcomes obtained to develop themselves.

\section{METHODS}

This development model used a research and development model with the ADDIE (Analysis Design Develop Implement Evaluate) instructional design model developed by Reiser and Mollenda. The design of the ADDIE development model consists of five main phases or stages, as shown in figure 1.

The first stage was the analysis phase, at the analysis stage was done to determine the learning problems in mathematics subjects faced by third grade elementary school students and the right solution for these problems. Both in the form of learning methods, learning strategies, learning motivation, learning conditions, and learning media. The needs analysis phase was carried out on mathematics learning teachers as well as third grade elementary school students. The second stage was design. At this stage the research was focused on designing learning media so that learning can achieve the expected goals, including the selection of subject matter in accordance with competencies, composing and designing the design of learning media, as well as collecting materials for stop motion animation learning media.

The third stage was the development stage. At this stage, the making of mathematical learning media in the form of stop motion-based animated videos that can be used on 
mobile phones by combining photos into a video and combining videos into a film that has been designed at the design stage. The fourth stage was the implementation stage. At this stage, the developed media was implemented according to their roles and functions, followed by the media assessment process by competent media experts in their fields to analyze the results of media learning and media assessment by mathematics learning practitioners in schools as material experts to assess the results of learning media, as well as assessment students to get a response about animation learning media. The last stage is the evaluation stage. At this stage, the evaluation of learning media was carried out, namely analyzing the extent to which the feasibility of learning media in mathematics has been developed. Actually, the evaluation stage can occur in each of the previous steps, which is called formative evaluation. The purpose was for revision needs, such as at the stage of the process of designing learning media and reviewing experts to provide input on the designs developed.

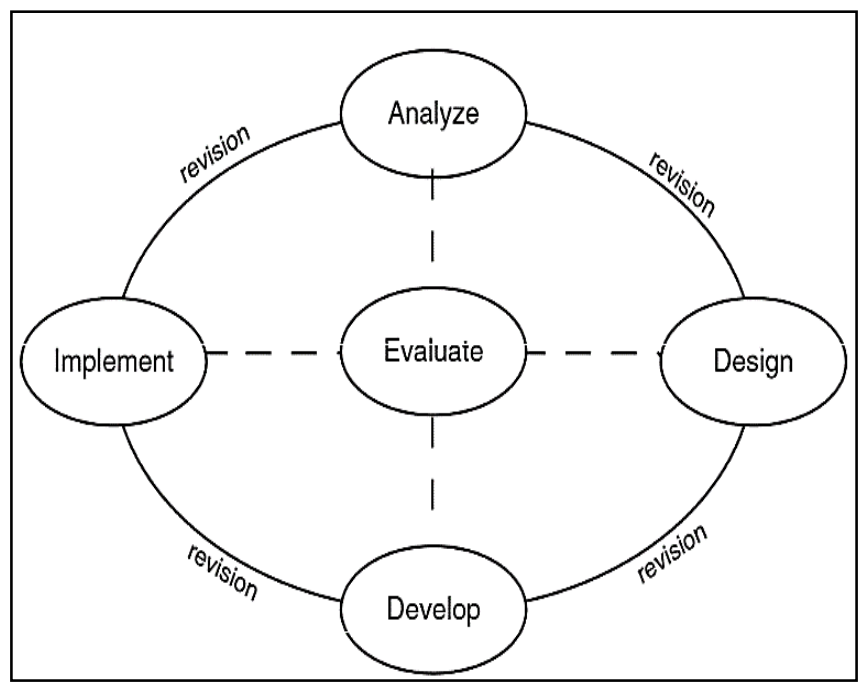

Figure 1. Design of the ADDIE Development Model (Branch, 2009)

\section{RESULTS \& DISCUSSION}

\section{Results}

The stages of this research activity are based on the 5 stages of the ADDIE model.

1. Analysis

The first step was to analyze the need to collect data. The process of needs analysis was carried out on three mathematics teachers and twenty students in the third-grade elementary school by direct interview. Needs analysis on teachers was done by oral and open interviews, while the needs analysis of students was done by written interview. Questions for teachers include frequently used methods, the need to develop new learning media, student responses to the learning process, learning materials, frequently used learning media, and teacher responses to learning media. While questions for students include interest in mathematics and responses to learning animation media. The following was interview excerpts of teachers and students to analyze learning media needs. 
Researcher and teacher 1

Researcher : What methods do you often use in learning math in class?

Teacher 1 : The method is not always the same, depending on the material. Now again a lot of practice so the first method is the demo, the second answer, and finally the direct practice.

Researcher : Why did you use the method?

Teacher 1 : Now that matches the material is direct practice.

Researcher : What is the student's response regarding the method do you use mathematics learning in class?

Teacher 1 : By practicing, he is immediately happy for those who really like it mathematics. But for those who don't like mathematics, he needs other methods such as learning to practice directly with his peers.

Researcher : During learning mathematics, what learning media do you often use in class?

Teacher 1 : The first media is the one in the class. Then yesterday from the publisher regarding money material there was media resembling real money. While the material rises flat using the surrounding objects inside.

Researcher : Why did you choose to use the media?

Teacher 1 : Cheap and in accordance with the material.

Researcher : What is the student's response to the media learning used?

Teacher 1 : Student response is happy. Especially yesterday regarding material money there is media like direct money. We make sales practices with cashiers and buyers and food sold.

Researcher : Have you ever used media-based learning? animated video?

Teacher 1 : Animated video for science lessons several times but for mathematics has never been.

Researcher : What if the video-based learning media are animated used in mathematics learning?

Teacher 1 : Surely children are happy because they are not monotonous

Researcher : Are there any obstacles to using media learning animated videos in mathematics learning?

Teacher 1 : Obstacles are in the facilities. because the projector must take turns.

Researcher : How did you suggest the math learning media-based on animated video?

Teacher 1 : Suggestions are to be tried if someone wants to make media mathematical animation. But it's better that the video has fraction material and wakes up flat because it's in the second semester and in the class it's also learning fractions.

Researcher and Teacher 2

Researcher : What methods do you often use in learning math in class?

Teacher 2 : Because they are thematic with direct learning, then games with demonstrations.

Researcher : Why did you use the method?

Teacher 2 : The first because it's fun.

Researcher : What is the student's response regarding the method do you use mathematics learning in class?

Teacher 2 : Children are happy because learning while playing makes they become more active, not monotonous in class.

Researcher : During learning mathematics, what learning media do you often use in class? 
Teacher 2 : Frequently used media, paper money, time material money, wake up flat with surrounding objects.

Researcher : Why did you choose to use the media?

Teacher 2 : The first one is easy to find.

Researcher : What is the student's response to the media learning used?

Teacher 2 : Fun if the learning media is directly on daily. like money using media money, they are happy. Because they are shoping with money.

Researcher : Have you ever used media-based learning? animated video?

Teacher 2 : Not yet found mathematical learning based on animation.

Researcher : What if the video-based learning media are animated used in mathematics learning?

Teacher 2 : Interesting, because children are not monotonous.

Researcher : Are there any obstacles to using media learning animated videos in mathematics learning?

Teacher 2 : Definitely a tool.

Researcher : How did you suggest the math learning media based on animated video?

Teacher 2 : Suggestions for the future are more on all the material in the class 3 especially even semester.

Researcher and student 1

Researcher : What do you think about math lessons?

Student 1 : Quite difficult but I like the lesson.

Researcher : Do you often study mathematics at home?

Student 1 : No.

Researcher : What media lessons are often used by teachers in mathematics learning?

Student 1 : Paper, ear plugs.

Researcher : What kind of media do you like?

Student 1 : Paper.

Researcher : Have you ever learned to use media in the form of learning animated videos?

Student 1 : No.

Researcher : Are you interested in learning mathematics using learning animation video media?

Student $1 \quad$ : Interested.

Researcher and student 2

Researcher : What do you think about math lessons?

Student 2 : Fun.

Researcher : Do you often study mathematics at home?

Student 2 : No.

Researcher : What media lessons are often used by teachers in mathematics learning?

Student 2 : Paper media.

Researcher : What kind of media do you like?

Student 2 : Paper.

Researcher : Have you ever learned to use media in the form of learning animated videos?

Student 2 : No.

Researcher : Are you interested in learning mathematics using learning animation video media?

Student 2 : Interested. 
Based on needs analysis, researchers found the fact that math learning will be more enjoyable if using a variety of interesting media, especially in the form of animated videos. However, teachers struggled to find appropriate media, which required the development of animation video-based media to meet the teachers ' needs in the mathematical learning process.

\section{Design}

The next step after the analysis phase was the design stage. At the design stage, the researcher can describe how the idea is owned. Various ideas and thoughts possessed by researchers were poured in the storyboard or commonly referred to as story scripts. In the storyboard, it clearly illustrated the storyline of the author's description of the animation learning media that will be created. After the story script or storyboard was completed, the next step was making various kinds of descriptions of the ideas of the researcher in the storyboard became part of the real animation material for the process of making animated learning media.

\section{Development}

Next step was the development stage. At this stage, the researcher made the results of the story script into a real product that can be used by students. The development stage is the most important stage. This stage started with taking pictures per image according to the story script or storyboard that the author has made at the design stage. After all the shooting in accordance with the story script or storyboard was completed, the results of the images were put together or the editing stage and created into a video equipped with the addition of music, the narrator's voice as material explanation, or other editing stages as a complement to the learning video developed. The following are the results of the development phase.

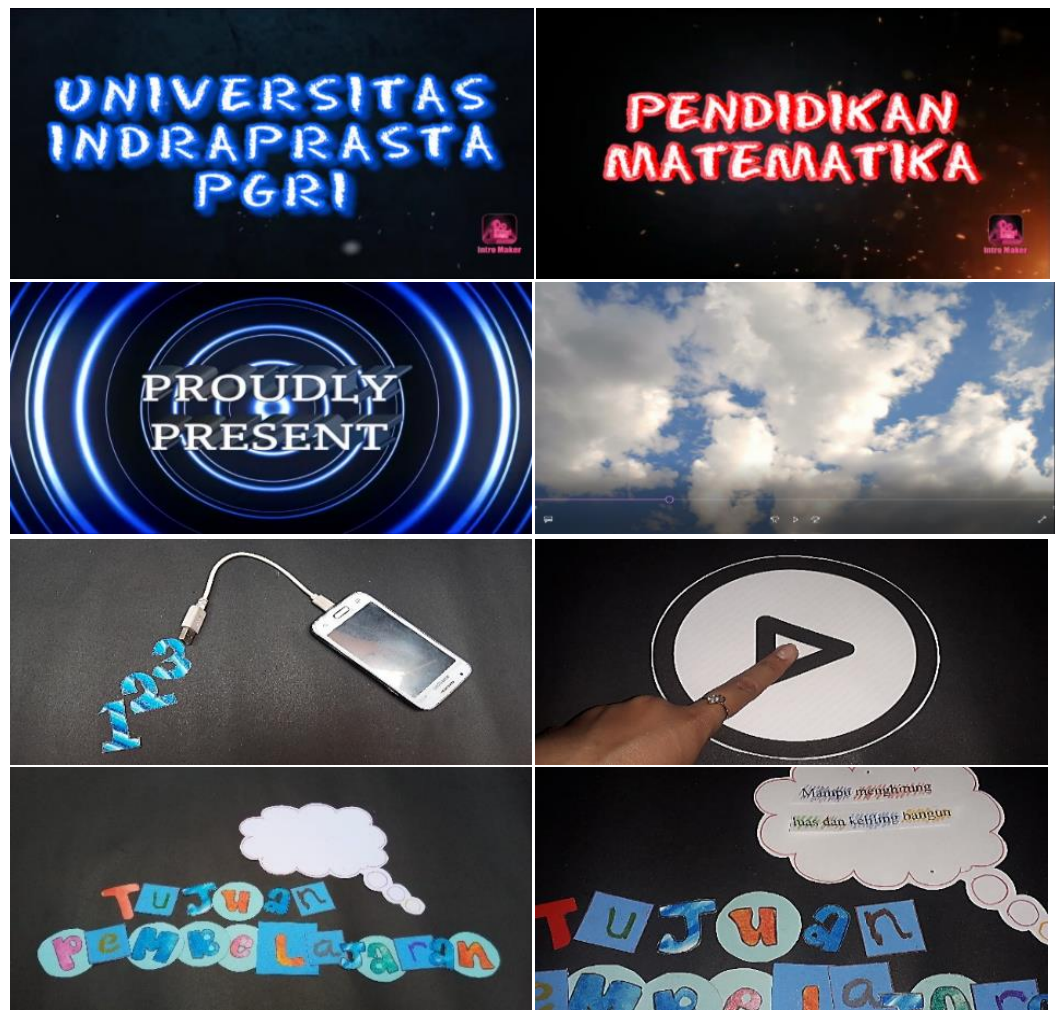

Figure 2. Display of Stop Motion Animated Video Opening Intro 


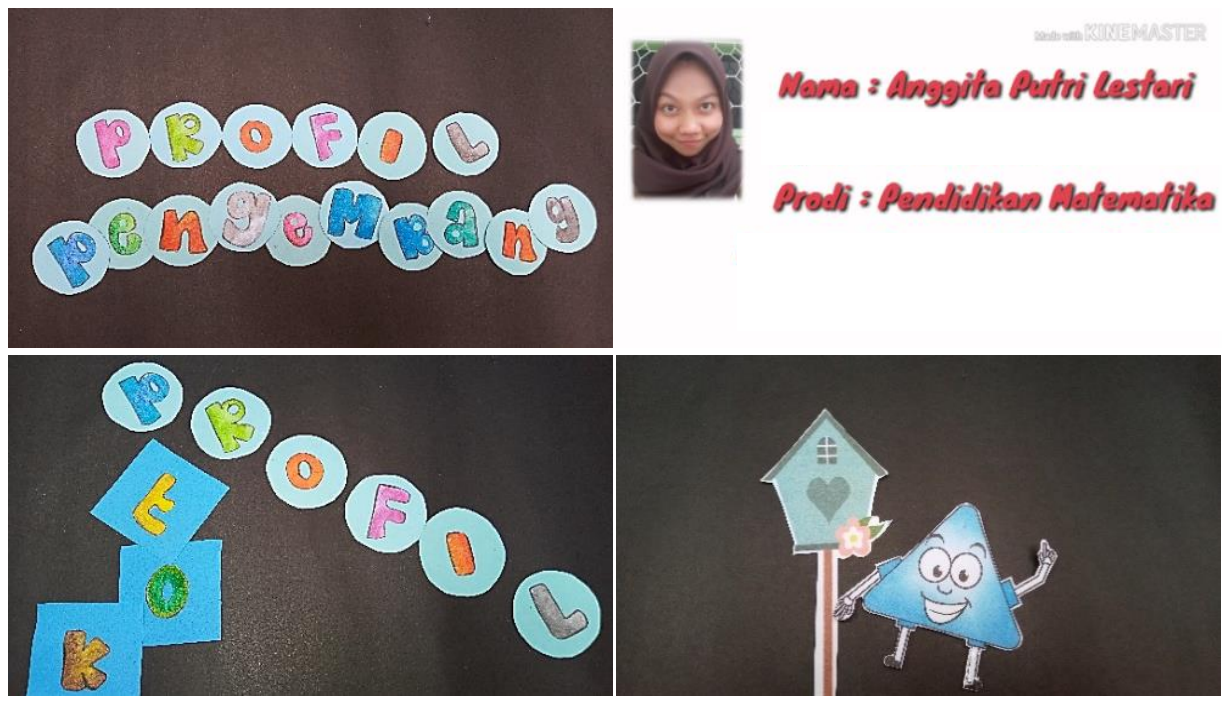

Figure 3. Display (Introduction) Stop Motion Animation Video Opening

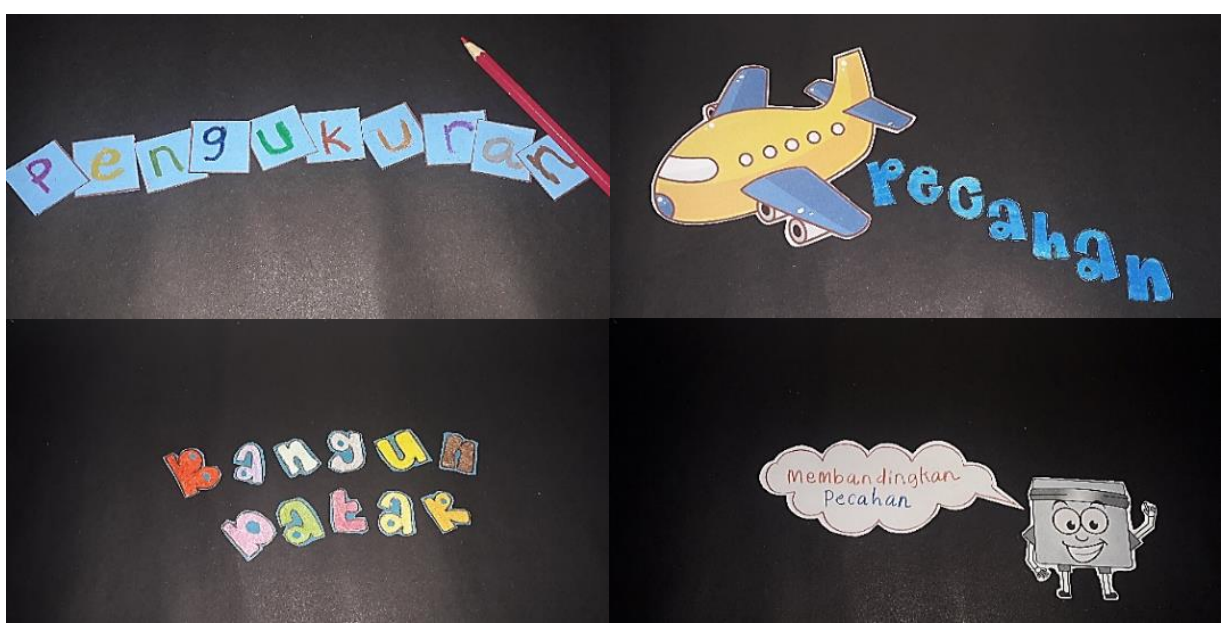

Figure 4. Display Title of Stop Motion Animation Video Content
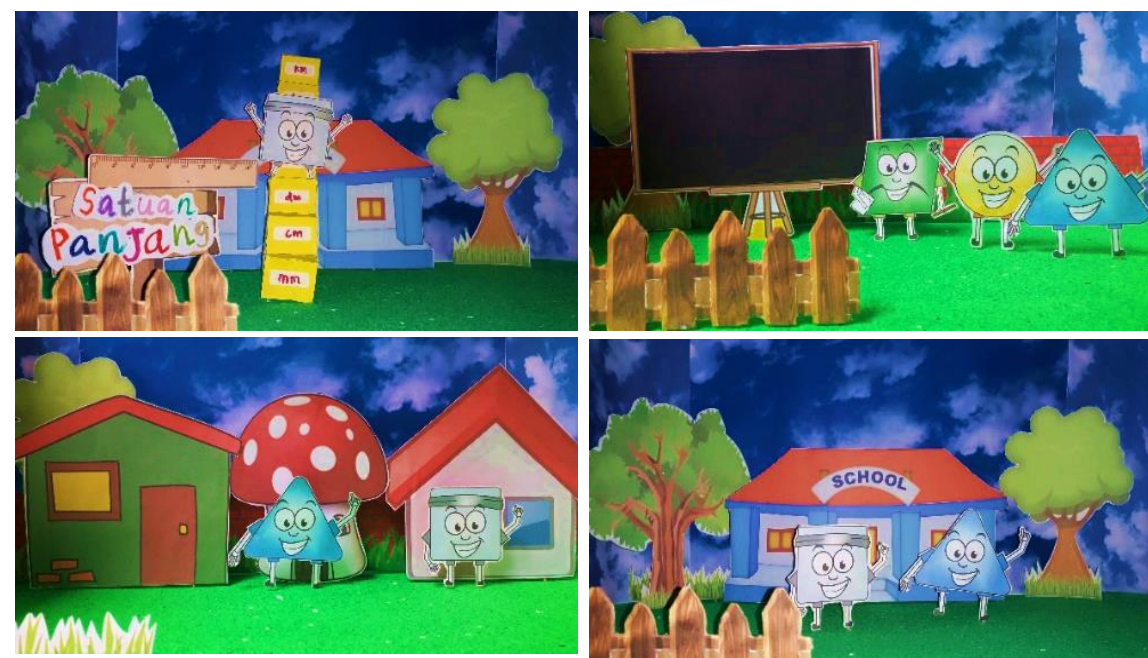

Figure 5. Display Opening of Stop Motion Animated Video Content 


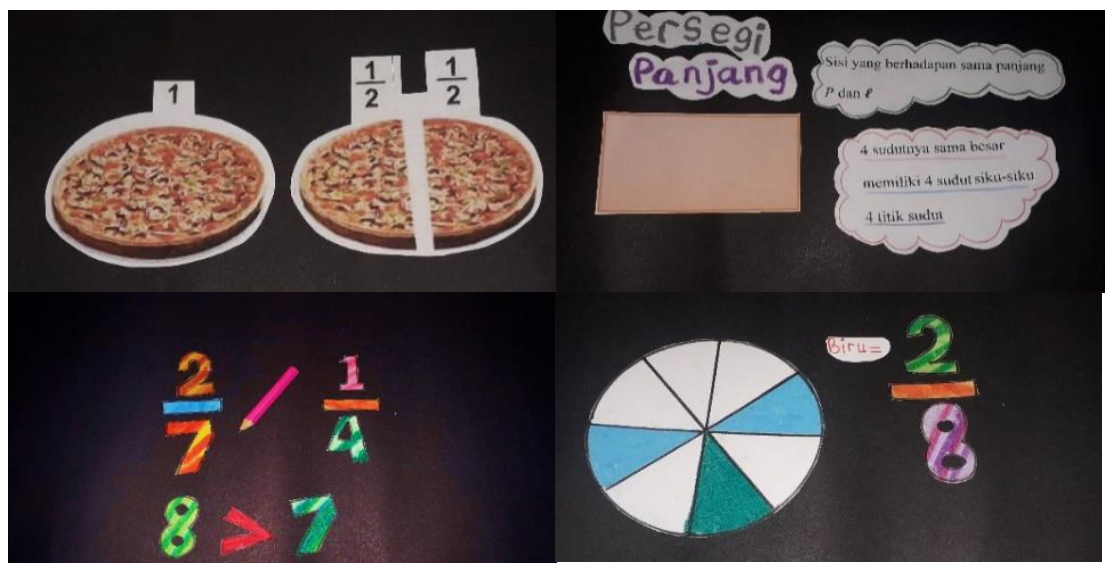

Figure 6. Display the contents of Stop Motion Animated Video Material



Figure 7. Display of Sample Practice Questions for Stop Motion Animated Video Material

3. Pak Danu baru membelah semangkanya menjadi 8 bagian. Ada 2 bagian yang dimakan Resti. Berapa bagian semangka yang dimakan resti jika ditulis dalam pecahan...

4. Pecahan empat per dua puluh delapan ditulis ......

5. Satu karung beras habis dalam waktu 14 hari. Jadi berapa bagian beras yang dipakai dalam setiap hari jika ditulis dalam bentuk pecahan ....

3. Pak Danu baru membelah semangkanya menjadi 8 bagian. Ada 2 bagian yang dimakan Resti. Berapa bagian semangka yang dimakan resti jika ditulis dalam pecahan... dimakan Resti $=\frac{2}{8}$

4. Pecahan empat per dua puluh delapan ditulis $\ldots \ldots \frac{4}{28}$

5. Satu karung beras habis dalam waktu 14 hari. Jadi berapa bagian beras yang dipakai dalam setiap hari jika ditulis dalam bentuk pecahan $\ldots . \frac{1}{14}$

Figure 8. Display of Exercise Questions Stop Motion Animated Video Material 

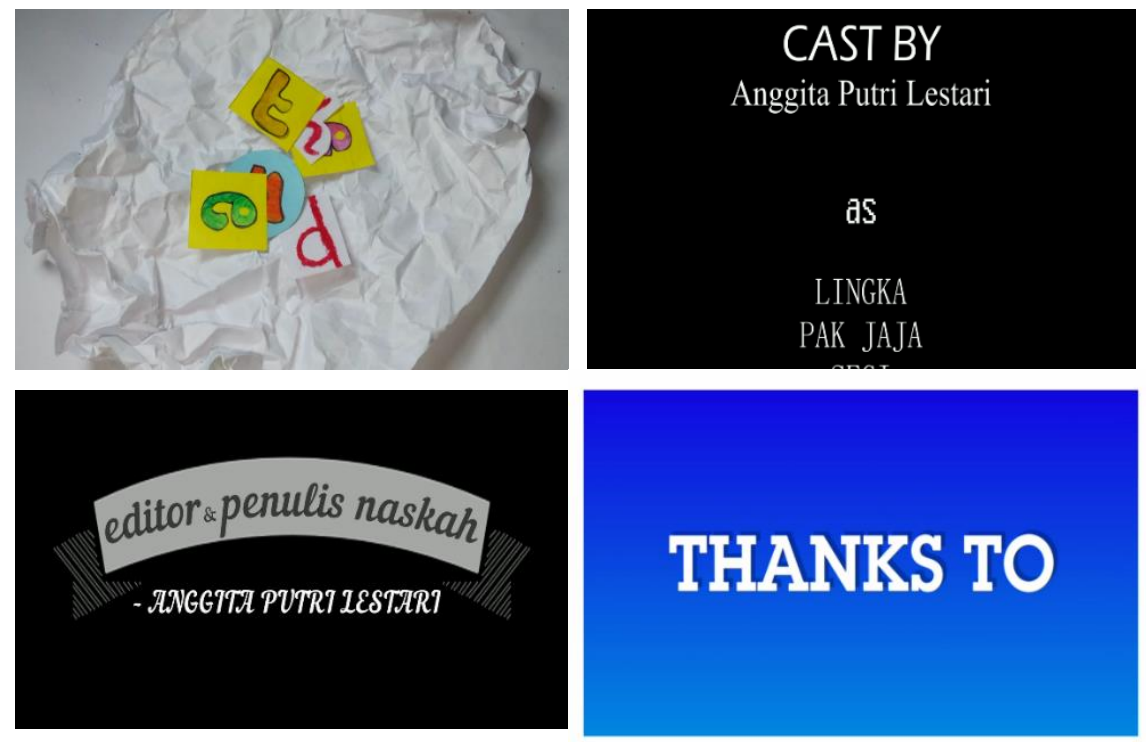

Figure 9. Display of the Stop Motion Animated Video Closing

4. Implementation

The fourth stage was the implementation. At this stage, the authors proposed the products that have been developed to be assessed by experts on their respective fields. This stage showed whether the developed product can be used as a medium for learning mathematics or not. Expert judgment was called expert validation. Validation was carried out by material experts and media experts. There are 3 material experts and 2 experts as well as an assessment of students' responses to find out whether the media can help students learn mathematics.

\section{Evaluation}

The last stage in this study was the formative evaluation stage. This evaluation aimed to determine what should be improved or revised so that the product was more systematic, effective, and efficient. In the product development process, formative evaluation was a necessity and takes place continuously. At this stage, consultations were conducted with interviews with development experts. This was intended to make the products produced become even better than before. In addition, the authors also always consulted continuously with material experts about the results of working on the product through indirect conversation.

\section{Discussion}

The results obtained from this development research were stop motion mathematics animation learning media for grade III elementary school. This audiovisual form was made with stop motion techniques accessed on cellphones or laptops and was compatible with the internet network. Therefore, it is easy and handy for students to increase the spirit of learning and make the learning process more fun (Wiratomo, Karim, \& Apriyanto, 2018). The use of smartphones in mathematics learning provides many benefits for teachers and students (Suprianto, 2019). It is flexible and can be used repeatedly according to the wishes of students (Forment \& Guerrero, 2008).

Developing a mathematics learning media based on stop motion animation for grade III elementary school students got them mathematical learning solution and also provided them to learn student responses to stop motion-based learning media. The development of 
mathematical learning media based on stop motion animation in accordance with current technology is made as a teacher's teaching aid in teaching mathematics in the classroom (Kurniawan, 2017). Rapid development computer technology and kind of things has made electronic learning a learning method accordance with material needs that have been developed proven to attract attention and interest in student learning (Sun, 2007).

Development of stop motion animation-based mathematics learning media for third grade students of Elementary School based on animated mathematics-based learning media, especially in learning materials in even semester. In addition, the learning media, especially mathematics lessons provide many benefits for the teacher and the students themselves in school. The benefits for teachers are (1) facilitating the teacher in the process of delivering material because it is helped by stop motion learning media, (2) the use of stop motion learning media makes learning more effective and efficient, (3) to help teachers increase student interest and motivation. Then, the benefits for students are: (1) can motivate students in learning mathematics with the help of learning media, (2) help students to learn independently outside the learning process, so the students can study at any time to improve student learning outcomes.

The results of this study using stop motion-based mathematics learning media show various kinds of benefits for teachers and students including, facilitating teachers in designing learning time allocations (Liana, 2016) and delivering material so that mathematics learning is more effective (Saragih, 2017) and directed (Trianto, 2013). This can be seen from the learning outcomes of students before and after using learning media (Peranginangin, 2019). Another benefit of using media is that students will more easily understand and master the material delivered by the teacher. It can motivate and increase interest in learning (Azizah, 2016) and foster the enthusiasm of learning mathematics for students (Ponza, 2018). By using multimedia-based learning media especially smartphones, it helps students learn independently so that they can improve student learning outcomes (Suprianto, 2019). In this case, the use of multimedia learning media namely animated films provides more opportunities for student learning experience (Suryaningsih, 2017). Furthermore, animated films are also able to increase student learning motivation because it is more interesting and fun (Sakat, 2012).

In a product, it certainly has advantages, including the learning media that the researchers developed. The advantages of the developed animated film based-learning media compared to another media are several. At first, on video animation products, researchers use cartoons related to mathematical material with expectation that it help students to remember things related to mathematics, but on other researchers' animated products the cartoons are used are not related to mathematics (Astriani, 2018). This is proven in the figure 10. Secondly, researchers' video animation products can be used in the long term, one semester of learning; while products made by other researchers can only be used for one chapter or one learning material. This is evidenced through another research title that was developing media animation film units of measurement in fourth grade elementary (Astriani, 2018) and the development of mathematical animated film sequences and class III SD series using stop motion studio (Wiratomo, 2018). Thirdly, the product developed by the researchers used the Movavi application for overall development so that it simplifies the development process; different from the product developed by other researchers which uses many applications so that it takes a long time in the development process. This is evidenced in the research study (Astriani, 2018) in developing learning media products the programs used are Adobe Illustrator CS3, Adobe Soundbooth CS3, Adobe Flash CS3 and Camtasia 8. Furthermore, the products produced by researchers were developed without applications using internet networks or offline, making it easier for researchers to develop mathematical animation products. In contrast to the results of other researchers, learning animation videos were developed with web-based animation 
software, such as Powtoon. Powtoon is an online application program that is on the internet and serves as a video-making application for presentations and learning media (Ponza, 2018).
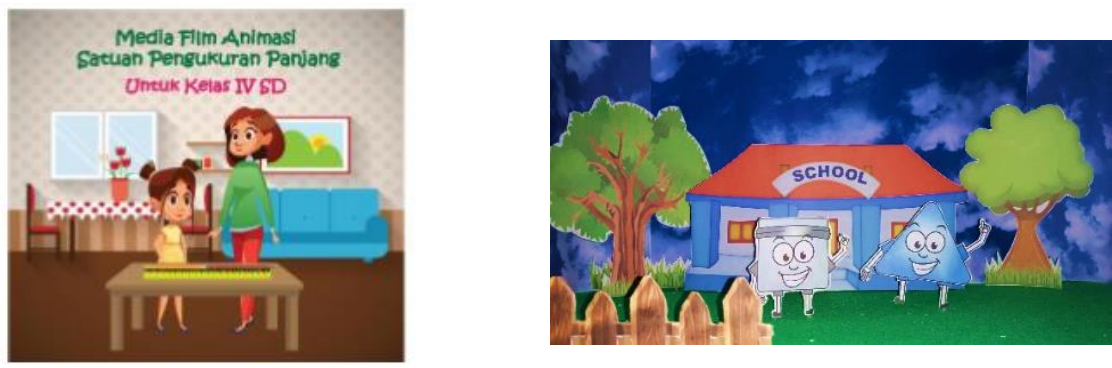

Figure 10. Products (Astriani, 2018) and Research Products

Based on the explanation above, it can be concluded that the development of stop motion mathematics animation learning media in grade III of Elementary School can bridge the use of mathematics learning media in the classroom. Thus it can facilitate students in the process of learning mathematics. Students will be more interested in learning with animated film learning media since there is a unification of graphics and sound, which can concretize learning material (Astriani, 2018) and has an attractive and interactive appearance (Garcia, 2007; Newby, 2000).

\section{CONCLUSION}

From the results of the study, it can be concluded that the use of stop motion mathematical animation learning media can increase students 'interest and motivation so that they can improve students' understanding of the material. Students' responses to stop motion animation learning media are very good This shows that almost all students are interested in stop motion animation learning media. The developed instructional media was the first time created by the researchers. Therefore, this learning media needs to be studied further by the next researcher. Moreover, It needs to be developed and retested in its entire features to students in various schools. Therefore, it can be used not only by third grade mathematics teacher MIT Nurul Iman Depok but also by other third grade math teachers both public elementary schools and private elementary schools.

\section{REFERENCES}

Arnis. (2017). Penggunaan media pembelajaran bervariatif untuk meningkatkan kompetensi mengajar guru di SDN 113 Pekan Baru. Jurnal Ilmu Pendidikan Sosial, Sains, dan Humaniora,3 (2), 265-272. https://ejournal.uinsuska.ac.id/index.php/suaraTeacher/article/viewFile/3603/2124.

Asma \& Lubis, M. S. (2017). Upaya meningkatkan kemampuan pemahaman konsep student kelas VIII MTs Al-Ilhamiyah Sidomulyo menggunakan pendekatan Realistic Mathematic Education (RME) pada sub materi pokok kubus dan balok tahun ajaran 2016/2017. Jurnal Pendidikan \& Matematika, 6 (1), 14-25. http://jurnal.uinsu.ac.id/index.php/axiom/article/759/563. 
Astriani, M.M. \& Alfahnum, M. (2018). Developing media animation film units of measurement in fourth grade elementary. Prosiding Diskusi Panel Nasional Pendidikan Matematika Universitas Indraprasta PGRI 2018,2 (1), 10-21. http://dx.doi.org/10.10.30998/pdpnpm.v2i0.63.

Azizah, S. (2016). Pengembangan media pembelajaran matematika berbasis muvizu di $\begin{array}{llllll}\text { kelas } 2 & \text { Sekolah Dasar. } J K P M, & 1 & \text { (2), 180-192. }\end{array}$ http://dx.doi.org/10.10.30998/jkpm.v1i2.1185.

Berney S and Betrancourt M. (2016). Does animation enhace learning? A meta- analysis. Computers \& Education, 150-167. http://dx.doi.org/10.1016/j.compedu.2016.06.005.

Branch, R. M. (2009). Instructional Design: The ADDIE Approach. New York: Springer.

Cope L. 2015. Math manipulatives: Making the abstract tangible. Delta Journal of Education,5 (1), 10-19. http://www.deltastate.edu/PDFFiles/DJE/spring-2015/djespring-2015-cope-final.

Forment, M., \& Guerrero, J. C. (2008). Moodbile: Extending moodle to the mobile on/offline scenario. IADIS International Conference Mobile Learning.http://www.iadisportal.org/digital-library/moodlbile-extending-moodleto-the-mobile-on/offline-scenario

Garcia, R. R, Quiros, J. S., Santos, R. G, Gonzales, S. M., and Fernanz M. (2007). Interactive multimedia animation with macromedia flash in descriptive geometry teaching. Computers and education. IL (3), 615-639. https://www.learntechlib.org/p/66505/.

Hernaeny, U. \& Alfin. E. (2015). Pengaruh strategi pembelajaran elaborasi terhadap hasil belajar matematika ditinjau dari motivasi belajar. Formatif: Jurnal Ilmiah Pendidikan MIPA, $\quad 5$ (3), 233-244. http://journal.lppmunindra.ac.id/index.php/Formatif/article/viewFile/644/568.

Hokanson, B \& Gibbons, A. (eds.). (2014). Design and Educational Technology. Educational Communications and Technology: Issues and Inovations 1. Switzerland: Springer. http://dx.doi.org/10.1007/978-3-319-00927-8_2.

Khotimah, H. \& Leonard. (2017). Pengaruh model pembelajaran quantum teaching dengan metode diskusi terhadap hasil belajar matematika. Prosiding Diskusi Panel Nasional Pendidikan "Menjadi Guru Pembelajar". Universitas Indraprasta PGRI, I (1), 77-85. https://journal.lppmunindra.ac.id/index.php/repository/article/view/1666/1288.

Kurniawan, C. (2017). Penerapan teknologi natural user (NUI) sebagai strategi pembelajaran terhadap retensi belajar. Jurnal Dimensi Pendidikan dan $\begin{array}{llll}\text { Pembelajaran, } & 5 & \text { (2), 56-63. }\end{array}$ https://journal.umpo.ac/index.php/dimensi//article/download/496/508.

Leonard \& Niky A. (2014). Pengaruh adversity quotient (AQ) dan kemampuan berpikir kritis terhadap prestasi belajar matematika. Jurnal Perspektif Ilmu Pendidikan, 28 (1), 55-64.

Liana, D. \& Leonard. (2016). Pengembangan media belajar berbasis komputer dalam pembelajaran matematika SMP. Seminar Nasional Pendidikan Matematika $\begin{array}{llll}\text { Universitas } \quad \text { Indraprasta } & \text { PGRI. } & 29-40 .\end{array}$ https://journal.lppmunindra.ac.id/index.php/repository/article/view/1054/982.

Listudentnti, R. Saputra, O. \& Windarti, I. (2015). Peranan media dalam pembelajaran. Jurnal Kesehatan, 6 (1), 102-105. https://ejurnal.polteknestjk.ac.id/index.php/JK/article/download/37/31.

Mahnun, N. (2012). Media Pembelajaran (Kajian terhadap langkah-langkah pemilihan media dan implementasinya dalam pembelajaran). Jurnal Pemikiran Islam, 37 (1), 27-35. http://ejournal.uin-suska.ac.id/index.php/anidaarticle/view/310. 
Meidawati, Y. (2014). Influence of supervised instructional enquiry approach on mathematical problem solving ability of junior high school students. Jurnal Pendidikan \& Keguruan, 2 (1), 1-10.

Muchlis, E. E. (2012). Pengaruh pendekatan pendidikan matematika realistik (PMRI) terhadap perkembangan kemampuan pemecahan masalah siswa kelas II SD Kartika 1.10 Padang. Exacta, 10 (2), 136-139. http://repository.unib.ac.id/519/

Newby, T., Stepich, D., Lehman, J. \& Russel J. (2000). Instructional for teaching and learning: designing instruction, integrating computers, and using media.Education Technology. New Jersey: Merril prentice hall.

Ogochukwu, N. V. (2010). Enhancing students intest in mathematics via multimedia presentation. African Journal of Mathematics and Computer Science Research, 3 (7), 107-113. http://www.academicjournals.org/AJMCSR.

Oktavia, I. (2015). Pengaruh pembelajaran kooperatif dan kreativitas belajar student terhadap pemahaman konsep matematika. JKPM, 1 (1), 16-30. https://journal.lppmunindra.ac.id/index.php/jkpm/article/view/889.

Peranginangin, S. A., Saragih, S., \& Siagian, P. (2019). Development of learning materials through PBL with Karo Culture Context to improve students' problem solving ability and self-efficacy. International Electronic Journal of Mathematics Education, 14 (2), 265-274. https://dx.doi.org/10.29333/iejme/571.

Ponza, P. J. R, Jampel, I N, \& Sudarma. I K. (2018). Pengembangan media video animasi pada pembelajaran siswa sekolah IV di Sekolah Dasar. Jurnal Jurusan Teknologi Pendidikan,9(2), 8-18. https://journal.undiksha.ac.id/

Prastya, A. (2016). Strategi pemilihan media pembelajaran bagi seorang guru. Universitas Terbuka, 294-302. https://repository.ut.ac.id/6518/1/TING2016ST2-03.

Primasari, R., Zulfiani, \& Herlanti, Y. (2014). Penggunaan media pembelajaran Madrasah Aliyah Negeri se-Jakarta Selatan. EDUSAINS, 6 (1), 68-72. http://journal.uinjkt.ac.id/index.php/edusains/article/view/1101.

Putra, F. G. (2016). Pengaruh model pembelajaran reflektif dengan pendekatan matematika realistik bernuansa keislaman terhadap kemampuan komunikasi matematis. Jurnal Pendidikan Matematika, 7 (2), 203-209. https://dx.doi.org/10.24042/ajpm.v7i2.35.

Sakat, A. A., Mohd Zin, M, Z., Muhamad, R., Ahmad, A., Ahmad, N. A., \& Kamo, M. A. (2012). Educational technology media method in teaching and learning progress.American Journal of Applied Sciences, 6 (9), 874-888. https://ukm.pure.elsevier.com/en/publications/educational-technology-mediamethod-in-teaching-and-learning-prog-2

Saragih, S., Napitupulu, E., \& Fauzi, M. (2017). Developing learning model based on local culture and instrument for mathematical higher order thinking ability.International Education Studies, 10 (6). https://dx.doi.org/10.5539/ies.v10n6p114.

Setyaningrum, W and Waryanto, N H. (2017). Developing mathematics edutainment media for Android based on students' understanding and interest: A teachers' review. Journal of Physics:Conference Series. http://dx.doi.org/10.10.1088/1742$\underline{6596 / 983 / 1 / 012093}$

Siregar, R. N. (2017). Persepsi student pada pelajaran matematika: studi pendahuluan pada student yang menyenangi game. Prosiding Temu Ilmiah X Ikatan Psikologi Perkembangan Indonesia. 224-232. http://jurnal.unissula.ac.id/index.ohp/ippi/article/view/2193/1655.

Sun P. C. And Cheng H. K. (2007). The design of instructional multimedia E-Learning: A media richness theory-based approach. Computer Education, IL (3), 662-676. http://dx.doi.org/j.compedu.2005.11.016.

Suparman, A. (2014). Desain Instruksional Modern: Panduan para Pengajar dan Inovator Pendidikan. Jakarta: Erlangga. 
Suprianto, A., Ahmadi, F., \& Suminar, T. (2019). The development of mathematics mobile learning media to improve students' autonomous and learning outcomes. Journal $\begin{array}{lllll}\text { of Primary } & \text { education. } & 8 & \text { (1), } & \text { 84-91. }\end{array}$ https://journal.unnes.ac.id/sju/index.php/jpe/article/view/19641

Suryaningsih, E. (2017). The effect of media for animation and simulation and self regulated learning on student biology achievement at the public senior higher school 25 Tangerang regency. Jurnal Pendidikan, 18 (1), 1-15. http://jurnal.ut.ac.id/index.php/JP/article/view/587.

Tambychik T. \& Meerah, T. (2010). Student's difficulties in mathematics problemsolving: what do you say? Procedia - Social and Behavioural Sciences Journal, 142-151. http://dx.doi.org/10.1016/j.sbspro.2010.12.020.

Trianto. (2013). Model Pembelajaran Terpadu dalam Teori dan Praktek. Jakarta: Prestasi Pustaka.

Wahyudi, Suyitno, H. \& Waluyo, St. B. (2018). Dampak perubahan paradigma baru matematika terhadap kurikulum dan pembelajaran matematika di Indonesia. Jurnal Ilmiah Kependidikan, 1 (1), 38-47. http://dx.doi.org/10.24176/jino.v1i1.2315.

Wiratmojo, P. \& Sasonohardjo. (2002). Media Pembelajaran Bahan Ajar Diklat Kewidyaiswaraan Berjenjang Tingkat Pertama, Lembaga Administrasi Negara.

Wiratomo, Y., Karim, A., \& Apriyanto, M. T. (2018). Pengembangan film animasi matematika barisan dan deret bilangan kelas III SD menggunakan stop motion studio. Seminar Nasional Pendidikan Matematika 2018, 1, 141-152. https://journal.uhamka.ac.id/index.php/senamku/article/view/2731. 